Article

\title{
What Role(s) Do Village Committees Play in the Withdrawal from Rural Homesteads? Evidence from Sichuan Province in Western China
}

\author{
Peng Tang ${ }^{1,2,3}$, Jing Chen ${ }^{1}$, Jinlong Gao ${ }^{4,5, * \mathbb{C}}, \operatorname{Min~Li}^{1}$ and Jinshuo Wang ${ }^{3}$ \\ 1 Department of Land Resource and Real Estate Management, Sichuan University, Chengdu 610065, China; \\ tp@scu.edu.cn (P.T.); ckj1217@foxmail.com (J.C.); limingg@scu.edu.cn (M.L.) \\ 2 Center for Social Development and Social Risk Control of Sichuan University, Chengdu 610065, China \\ 3 Department of Geography, Planning and Environment, Radboud University, \\ 6525 Nijmegen, The Netherlands; j.wang@fm.ru.nl \\ 4 Key Laboratory of Watershed Geographic Sciences, Nanjing Institute of Geography and Limnology, \\ Chinese Academy of Sciences, Nanjing 210008, China \\ 5 Department of Planning and Landscape Architecture, University of Wisconsin-Madison, \\ Madison, WI 53706, USA \\ * Correspondence: jlgao@niglas.ac.cn
}

Received: 25 October 2020; Accepted: 25 November 2020; Published: 27 November 2020

\begin{abstract}
Village committees, as grassroots spontaneously formed by rural collective members in China's hierarchy system, play an irreplaceable role in the management of rural public affairs. Based on the filed survey dataset taken from three pilot counties/districts in Sichuan province, we explored the significant role that village committees played in farmers' withdrawal from rural homesteads (WRH). Our empirical results, according to binary logistic regression (BLR) modelling, indicated that the WRH was significantly affected by the triple roles of village committees, among which information intermediary was the most effective followed by the trust builder and then the coordinated manager. Firstly, village committees' involvement facilitated the WRH by improving policy transparency and decreasing information cost. Secondly, the depth of village committees' participation (i.e., being involved in multiple phases) positively affected the WRH given its signification of the participation of farmers. Whereas the breadth of participation (i.e., considering various demands of different participants) negatively affected the process of WRH by reducing the decision-making efficiency. Thirdly, farmers' trust in institutions played a positive role in the WRH, but their confidence in village cadres had limited impact. We therefore argue that promising village committees should act as "all-round stewards" in the decision-making of rural households, which not only includes the transmit of information between those above and those below, but also needs to actively strive for farmers' trust by letting their voice heard. Based on our empirical findings, this paper finally proposed some policy suggestions, such as strengthening mutual communication, empowerment of rural grassroots, encouraging farmers' participation and improving formal institutions.
\end{abstract}

Keywords: rural homestead reform; grassroots village; farmers' willingness; land use transition; rural revitalization

\section{Introduction}

The depopulation of rural areas (excluding exurbs along the urban-rural continuum) is observed across the globe [1-3]. Since the reform and opening-up in the late 1970s, China has urbanized at an unprecedented speed and has perhaps experienced the world's greatest rural-to-urban migration ever [4-6]. Nevertheless, construction land in rural China has increased steadily since the 1990s with 
the registered population declining, which is recognized as the 'paradox of development' or 'dilemma of governance' [7-10]. This phenomenon has inevitably led to a far-reaching restructuring of physical and human landscapes in rural China and the inefficiency of land use and 'village hollowing' as well [11-14]. As Zhou et al. [8] report, there had been 2.7 million rural settlements in China, covering an area of 19.13 million hectares, of which about one-ninth is underutilized in 2015.

To address the issues of 'village hollowing' and achieve sustainable rural development, the Chinese government has launched a set of rural land-use reforms, which is called rural revitalization $[7,8,15]$. Withdrawal from rural homesteads (WRH) is expected to be helpful in accelerating the restructuring of rural areas and balancing urban-rural development $[11,15,16]$. Given the dualistic nature of urban-rural land use system, the WRH in China is widely considered as a hybrid and contested process involving numerous stakeholders $[14,15,17,18]$.

Generally, two strands of literature are related to the local and external studies of WRH in China. In the first strand, researchers focus on analyzing and modeling farmers' willingness to withdraw from rural homesteads and spatial heterogeneity features with the help of pilot survey datasets, geographical information, and socio-economic variables from statistical yearbooks [17-20]. Relying on the technical advancements in data mining technology, GIS spatial modeling, remote sensing, and spatial econometrics, these geographical studies have identified individual attributes (e.g., age, gender, education, occupation), household characteristics (e.g., family size, homestead area, total family income, and urban housing status), and regional configurations (e.g., village location, average arable land area, urban-rural income gap) as key factors influencing WRH in China [16,19-22]. In the second strand, processes of withdrawal from rural homesteads are examined from the perspective of institutions and governance mostly through qualitative methods (e.g., text analysis, social network approach) $[11,14,15,23,24]$. This line of political science literature has demonstrated that WRH in China is inextricably intertwined with the separation of the "three rights of rural land" (i.e., collective ownership, land contract right, and land use right), dual-track household register (hukou) and social security systems, as well as the community cohesion and rural identity [25-30].

These parallel but distinct research traditions limit a comprehensive understanding of the WRH in China, because of their neglecting of the role played by village committees-agents of collective economic organizations. Given that homesteads in rural China are collectively owned and serve as the last safety net for survival by the majority of farmers with the Chinese bifurcated social security system $[11,27,31]$, it is reasonable to fully understand the reason why farmer's willingness represents a key factor in the withdrawal process $[16,17,19]$. Wang et al. [32] find that farmers can hardly understand the legal regulations regarding property rights of rural homesteads and any other institutional arrangements, while the village committee, as a grassroots organization having deep daily contact with rural dwellers, plays an irreplaceable role in local governance $[33,34]$. In this sense, it is important to analyze village committees' role(s) in the WRH.

Stemming from both theories on behavioral economics and the rural system reform reality, this research broadened the debate about different roles played by village committees in the WRH by developing a comprehensive framework in a testbed of rural China. While most of the research foci have been attached to the WRH in China, the other side of the nexus-village committees-has often been reduced to the observed intermediary and intervention effects [35]. There seems to be a lack of knowledge about the roles and impacts of village committees concerning the WRH. Furthermore, the WRH-a key part of land use transition - plays an important role in facilitating land use transition [4]. Specifically, the WRH involves changes in both dominant and recessive morphologies of land use. This work can to some extent enrich our understanding of the trajectory and impetus of land use transition, especially in the aspect of recessive morphologies of land use.

Bearing the aforementioned background in mind, this research investigates the role(s) of village committees influencing farmers' willingness to withdraw from rural homesteads, and explores how village committees affect households' decisions regarding the WRH. Then we conduct an empirical test by drawing on the case of Sichuan Province in western China. In the following sections, we first 
propose a conceptual framework to analyze the influencing mechanisms of village committees in WRH. Section 3 provides a brief review of the study area and explains the data and methodology. In Section 4 , we examine the influencing factors of WRH in 24 villages in Sichuan Province. Section 5 discusses the major findings and policy implications. Finally, Section 6 concludes.

\section{Background and Conceptual Framework}

WRH refers to the transfer of homestead use right to collective economic organizations under farmers' voluntary application with compensation from the government. After transferring, farmers can either live in concentrated settlements nearby or directly migrate to cities. However, house-losing farmers tend to resettle in concentrated residential zones rather than migrating to cities, given that most farmers can hardly afford urban housing and have to earn their lives by engaging in agricultural activities [22]. In China, WRH is mostly dominated by local governments at the county/township-levels. These local authorities tend to give grassroots (village committees) greater autonomy regarding the withdrawal procedure, compensation standards and resettlement planning, and introduce enterprises to implement the project of land remediation. Within the context of administrative decentralization and community empowerment, the leading role of village committees in rural governance is increasingly recognized by both scholars and policymakers [36-38]. The participation of village committees is essential for WRH in at least the following three aspects (Figure 1, drawn by authors).

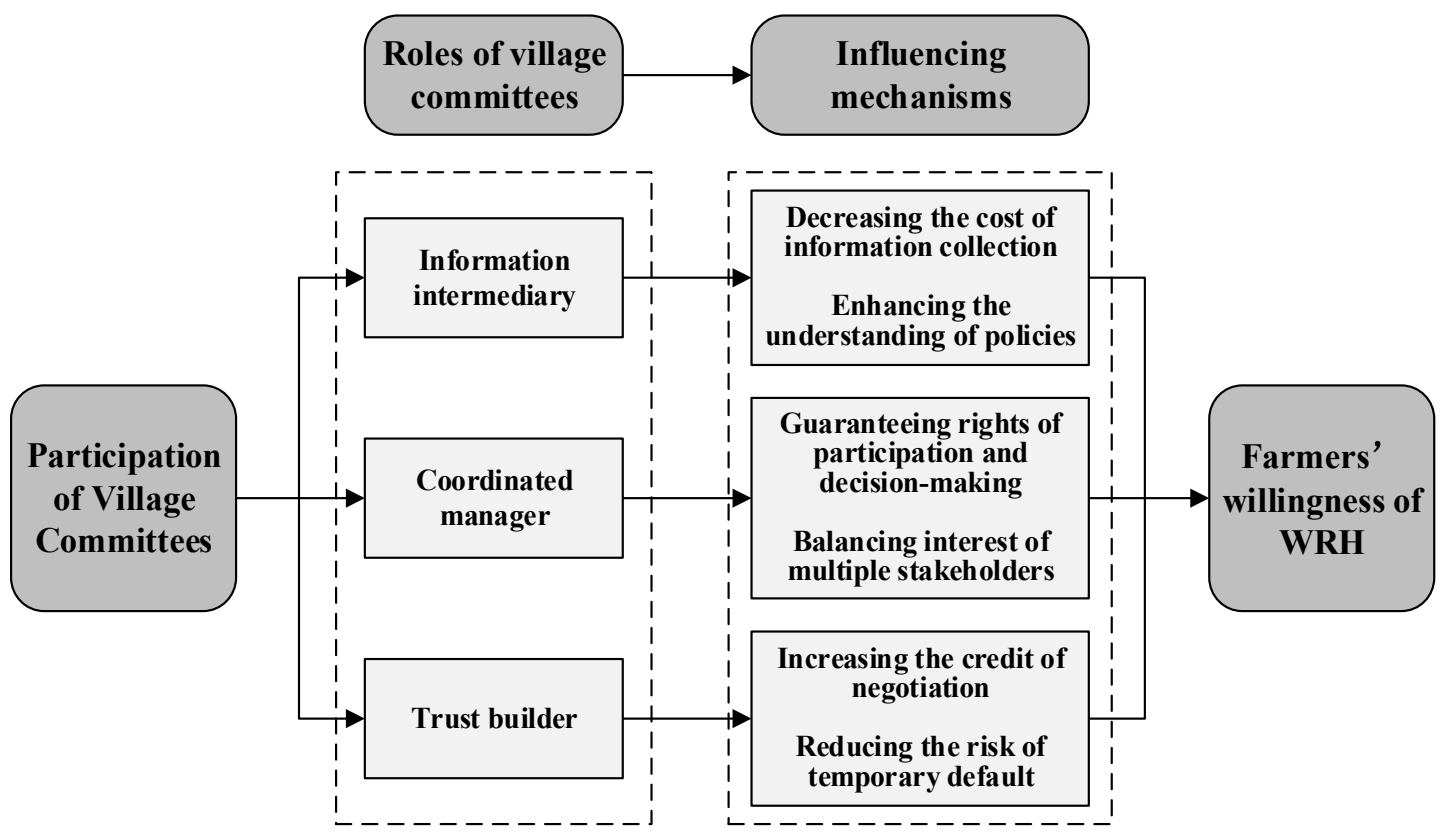

Figure 1. Influencing mechanisms of village committees on the withdrawal from rural homesteads (WRH) in China.

\subsection{Information Intermediary}

In recent years, development research has increasingly focused on the importance of access to information and found it a critical role in farmers' better understanding of governmental policies and in reducing their uncertainty about eventual benefits [39]. Despite recent advances in communication techniques, access to information in some rural communities is still restricted by geographical distance and administrative areas [40]. Besides, rural communities in developing countries are naturally oral societies, and thus prefer information delivered through face-to-face communication [41]. Specifically, farmers in China rely heavily on village cadres as sources of authoritative information about rural land use due to relevancy in context and content [42,43]. Therefore, village committees, as grassroots 
in China's hierarchy administrative system, as an intermediary, play a significant role in delivering information to villagers.

In a nutshell, the village committees' role, as the information intermediary, is mainly shown through propagating approaches and information transparency. First, policy propagating approaches used by village committees affect farmers' understanding of relevant information. Diversified approaches of propaganda do not only advance the access to information, it may also enhance farmers' understanding and acceptance through exposure to new ideas and an increased amount of information [44]. Secondly, information transparency is the key to policy implementation. In theory, information transparency can be understood from two perspectives, namely procedure transparency and legitimacy transparency. The former is a transparent flow of information, through which participants need to be informed about the course of the process and expected inputs. The latter means transparency on the legitimacy of decision-making [45].

\subsection{Coordinated Management}

As noted at the outset, the withdrawal of homesteads in rural China is a complex process involving a multitude of activities conducted by numerous participants/stakeholders [14,18]. Village committees also play an irreplaceable role in the management of rural daily affairs. Given that successful self-organization by farmers can greatly reduce holdout problems and costs of negotiation than the public organized structure of governance, involving village committees in WRH is usually more efficient and effective [46]. In a neoliberal governance regime, village committees can increase the legitimacy of farmers' participation in WRH and guarantee their interests by giving villagers a voice and making it heard by superior authorities [47].

In practice, village committees take the lead in formulating implementation plans of WRH and convening villagers to select their preferred one(s), and take part in setting standards of housing and compensation for house-losing farmers as well. Village committees can transmit farmers' demands for community remediation to up-level authorities in a timely manner and maximize their compensation. Meanwhile, village committees, as the agent for all villagers, are responsible for selecting developers for resettlement (valid candidates are usually selected in means of public bidding) and supervising the progress and quality of related projects. With local knowledge and farmers' lifestyle in mind, village committees can also coordinate and balance the interests of different stakeholders. In this regard, village committees' involvement in WRH can not only guarantee farmers' rights of participation in decision-making but also help to protect the interests of those house-losing farmers. Inferentially, the more deeply village committees participate and/or the more democratic their decision-making is, the higher degree of farmers' willingness is to withdraw from their homesteads.

\subsection{Trust Building}

As a precondition for a well-managed contract, trust can help to reduce transaction costs and maintain stable relations among participants [48]. Specifically, mutual trust can save bargaining time before the transaction, and decrease resources in the implementation of a contract [49]. Farmers' trust in village committees can form closer social relations in communities and significantly improve the efficiency of response to problems [50]. Scholars have pointed out that low trust and experiences with low reciprocity could lead to a decrease in farmers' willingness to participate in community management schemes [51].

In theory, farmers' trust in village committees can be divided into interpersonal trust (i.e., trust in village cadres and their daily works) and institutional trust (i.e., trust in political institutions and village committees' management schemes) [52]. From the perspective of interpersonal trust, negotiation cost can be decreased on WRH, if the interpersonal relationship between farmers and village cadres is harmonious. Otherwise, more procedural works would be needed because of the asymmetrical distribution of power [53] and farmers' willingness to sign the contract of WRH would decrease as a corresponding increase in the transaction cost [54]. In other words, the higher level of trust can 
increase the sense of credit in negotiation processes and good expectations of the results, while reducing negotiation resistance and stimulating more farmers to withdraw from the rural homesteads. Besides, institutional trust depends on the "reputation mechanism" of village committees which is developed from the long-term cooperation between the village committee and farmers [55]. Farmers' trust in village committees leads to a higher degree of acceptance of relevant policies and a lower risk of temporary default. In summary, farmers' trust in grassroots policies (i.e., institutional trust) and village cadres (i.e., interpersonal trust) may have a positive influence on the WRH.

\section{Research Setting}

\subsection{Study Area and Data Collection}

As illustrated in Figure 2, a total of 24 administrative villages in three counties/districts (i.e., Luxian, Pidu, Qionglai) in Sichuan Province were selected as samples. The primary reason to take these regions as examples is that these areas have carried out pilot projects of rural homesteads reform in China on one hand. On the other hand, these pilot regions are at different levels of economic development and topographical characteristics, which might be helpful in increasing the representativeness of samples To be specific, Luxian County is one of the 15 national level pilots on rural homestead acquisition and approval, paid use of homesteads, and mortgage loans [7]. Situated in Chengdu, the provincial capital of Sichuan, Pidu District and Qionglai City are exploring rural homesteads exit mechanisms within the context of urban-rural integration, comprehensive land remediation, high-standard farmland conservation, new countryside building, and rural vitalization [56]. Topographically, the sample villages are located in the southern mountain area (Luxian and Qionglai) and Chengdu plain (Pidu), respectively. Additionally, the level of economic development in the three regions varies. Pidu is an economically developed region with its per capita GDP over RMB 73,000 in 2019; Luxian is relatively underdeveloped with a per capita GDP of RMB 43,400 and the lowest urbanization rate; Qionglai is in the middle of its two counterparts with a per capita GDP of RMB 53,413.

Based on the population size and geographic location (e.g., distance to urban areas and terrain conditions), we chose a total of 24 sample villages, most of which were pilots of homestead reform. Considering the differentiated progress of reform in villages, we also took local governments' suggestions regarding the collection of sample villages into account. Concerning the specific method of household sampling, we decided to randomly select 20-30 households in each village and finally interviewed a total of 310 households from August to October 2018. After the test of the validity of questionnaires, we received 308 valid responses (Table 1). Firstly, the gender ratio was balanced, and male farmers had a higher degree of willingness to withdraw from homesteads than their female counterparts. In terms of age, respondents between 40 and 70 years old were the majority (70.8\%), and farmers aged 30 to 39 had the lowest willingness of WRH. Regarding the educational level, most respondents received the education of primary school or below, and only $37.0 \%$ received a secondary or above education. The data showed that farmers with higher education levels tend to have a higher degree of willingness. For the household income, the majority ranged from RMB 15,000 to RMB 30,000, and $89.3 \%$ of the total households earned more than RMB 10,000 annually. Coincidently, we hereby assume that farmers with higher incomes are more willing to withdraw from homesteads. Moving to the family size, the majority was made up of five or six members, followed by three/four-person families. Only $8.1 \%$ were single or double families. Households with more family members were more inclined to withdraw from their homesteads. 


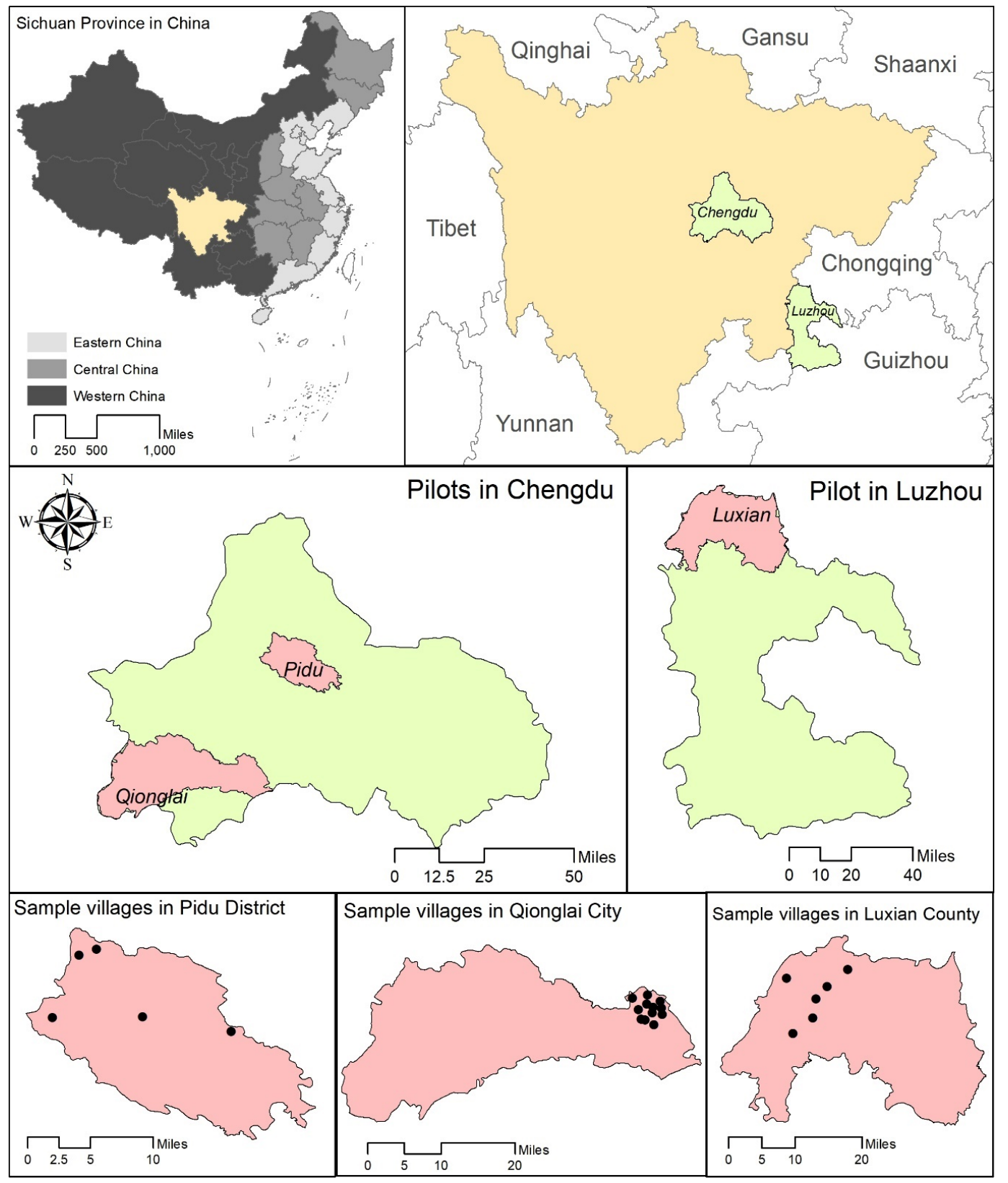

Figure 2. Study area and location of sample villages.

Table 1. Profile of survey respondents in sample villages $(n=308)$.

\begin{tabular}{|c|c|c|c|c|c|c|c|}
\hline Feature & Options & $\begin{array}{l}\text { Percentage } \\
(\%)\end{array}$ & $\begin{array}{l}\text { Willing of } \\
\text { WRH (\%) }\end{array}$ & Feature & Options & $\begin{array}{l}\text { Percentage } \\
(\%)\end{array}$ & $\begin{array}{l}\text { Willing of } \\
\text { WRH (\%) }\end{array}$ \\
\hline \multirow{2}{*}{ Gender } & Male & 42.9 & 83.3 & \multirow{6}{*}{$\begin{array}{c}\text { Household } \\
\text { annual net income } \\
\text { (RMB 10k) }\end{array}$} & $<0.5$ & 10.7 & 65.4 \\
\hline & Female & 57.1 & 79.5 & & {$[0.5,1)$} & 13 & 75.0 \\
\hline \multirow{4}{*}{ Age } & $30-39$ & 6.4 & 56.3 & & {$[1.5,3)$} & 24.7 & 81.6 \\
\hline & $40-49$ & 24.2 & 80.8 & & {$[3,5)$} & 22.1 & 84.2 \\
\hline & $50-59$ & 20.8 & 79.8 & & {$[5,7)$} & 9.7 & 100.0 \\
\hline & $\geq 80$ & 2.2 & 85.7 & & & & \\
\hline \multirow{4}{*}{ Education } & Primary school and below & 63 & 82.5 & \multirow{4}{*}{ Family size } & $1-2$ & 8.1 & 80.0 \\
\hline & Junior high school & 25.3 & 82.1 & & $3-4$ & 35.1 & 81.5 \\
\hline & Senior high school & 6.5 & 75.0 & & $5-6$ & 48.7 & 80.0 \\
\hline & Vocational/technical college & 1.6 & 80.0 & & $7-8$ & 6.8 & 85.7 \\
\hline
\end{tabular}




\subsection{Empirical Models and Variable Specifications}

We first employed binary logistic regression (BLR) to estimate the impact of village committees on farmers' willingness of WRH. BLR is a nonlinear statistical method of regression analysis for binary dependent variables $[57,58]$. In this study, farmers' willingness of WRH $(Y)$ is a binary dependent variable with values of 0 (unwilling) and 1 (willing). Given the multiple impacts of China's transition on WRH at multiple levels, the overall probability of WRH is $P(Y=1)$. Thus, the BLR model can be framed as follows:

$$
\begin{gathered}
P\left(Y=1 \mid x_{1}, x_{2} \cdots, x_{m}\right)=\exp \left(\beta_{0}+\sum \beta_{i} x_{i}\right) /\left(1+\exp \left(\beta_{0}+\sum \beta_{i} x_{i}\right)\right) \\
\operatorname{logit} P\left(Y=1 \mid x_{1}, x_{2} \cdots, x_{m}\right)=\ln \left(\frac{P}{1-P}\right)=\beta_{0}+\sum_{i=1}^{m} \beta_{i} x_{i}
\end{gathered}
$$

Here, $x_{i}$ is the explanatory variables, and $\operatorname{logit} P(Y=1)$ is a linear combination function of the explanatory variables. Parameters $\beta_{i}$ denote the partial regression coefficient to be estimated. After variable standardization, the obtained $\beta_{i}$ may reflect the relative influence of each independent variable on dependent variables. Drawing upon the aforementioned conceptual framework, four groups of explanatory variables were selected to model the influence of village committees on farmers' willingness of WRH (Table 2).

\begin{tabular}{|c|c|c|c|c|}
\hline Variables & Definitions & Mean & S.D. & Expected Sign \\
\hline \multicolumn{5}{|l|}{ Information intermediary } \\
\hline Diversity of publicity & $\begin{array}{l}\text { The number of specific ways for village } \\
\text { committees to promote policies about WRH. } \\
\text { The value ranges from } 1 \text { to } 6 \text {. }\end{array}$ & 1.675 & 0.908 & + \\
\hline Information transparency & $\begin{array}{l}\text { Level of publicity and transparent of WRH } \\
\text { policies and other related information: very } \\
\text { opaque }=1 \text {; opaque }=2 \text {; general }=3 \text {; } \\
\text { transparent }=4 \text {; very transparent }=5\end{array}$ & 3.299 & 0.976 & + \\
\hline \multicolumn{5}{|l|}{ Coordinated management } \\
\hline Workload of village committees & $\begin{array}{l}\text { The number of specific works that village } \\
\text { committees participate in during the process } \\
\text { of WRH. The value ranges from } 0 \text { to } 6 \text {. }\end{array}$ & 3.240 & 2.003 & + \\
\hline $\begin{array}{l}\text { Degree of democratic } \\
\text { decision-making }\end{array}$ & $\begin{array}{l}\text { The frequency of the consultation organized } \\
\text { by village committees during the process of } \\
\text { WRH: never = } 1 \text {; hardly = 2; often = } 3 \text {; } \\
\text { usually }=4\end{array}$ & 3.010 & 1.087 & + \\
\hline \multicolumn{5}{|l|}{ Trust building } \\
\hline Interpersonal trust & $\begin{array}{l}\text { Whether village committees are trusted by } \\
\text { farmers in daily work: distrust }=1 \text {; less trust } \\
=2 \text {; general }=3 \text {; trust }=4 \text {; very trust }=5\end{array}$ & 2.750 & 1.0734 & + \\
\hline Institutional trust & $\begin{array}{l}\text { Whether the rules and regulations } \\
\text { established regarding the WRH can be } \\
\text { trusted by farmers: distrust }=1 \text {; less trust }=2 \text {; } \\
\text { general = 3; trust }=4 \text {; very trust }=5\end{array}$ & 3.273 & 1.057 & + \\
\hline \multicolumn{5}{|l|}{ Control variables } \\
\hline Age & Age of all respondents & 55.536 & 13.614 & - \\
\hline Gender & Male $=1 ;$ female $=2$ & 1.571 & 0.4957 & - \\
\hline Educational level & $\begin{array}{l}\text { Primary school and below }=1 ; \text { junior high } \\
\text { school }=2 \text {; senior high school }=3 \text {; vocational } \\
\text { or technical secondary college }=4 \text {; } \\
\text { Undergraduate and above }=5\end{array}$ & 1.575 & 0.950 & + \\
\hline Proportion of migrants & $\begin{array}{l}\text { The ratio of migrant workers in households } \\
{[0,5 \mathrm{k})=1 ;[5 \mathrm{k}, 10 \mathrm{k})=2 ;[10 \mathrm{k}, 15 \mathrm{k})=3 ;[15 \mathrm{k}}\end{array}$ & 0.402 & 0.238 & + \\
\hline Household annual net income & $\begin{array}{l}30 \mathrm{k})=4 ;[30 \mathrm{k}, 50 \mathrm{k})=5 ;[50 \mathrm{k}, 70 \mathrm{k})=6 ;[70 \mathrm{k} \\
90 \mathrm{k})=7 ;[90 \mathrm{k},+\infty)=8\end{array}$ & 4.000 & 1.808 & + \\
\hline
\end{tabular}

Table 2. Definition and descriptive statistics of each variable. 
Table 2. Cont

\begin{tabular}{|c|c|c|c|c|}
\hline Variables & Definitions & Mean & S.D. & Expected Sign \\
\hline \multicolumn{5}{|l|}{ Control variables } \\
\hline Area of the contracted land & $\begin{array}{l}\text { The actual total area of contracted land } \\
\text { owned by households }\end{array}$ & 3.021 & 1.898 & $+/-$ \\
\hline Area of the homestead & $\begin{array}{l}\text { The actual area of the original homestead } \\
\text { owned by households or having } \\
\text { been withdrawn. }\end{array}$ & 289.698 & 299.368 & $+/-$ \\
\hline $\begin{array}{l}\text { Land used period of the } \\
\text { homestead }\end{array}$ & $\begin{array}{l}\text { The land used period of the original } \\
\text { homestead owned by households or having } \\
\text { been withdrawn }\end{array}$ & 24.666 & 11.103 & - \\
\hline
\end{tabular}

\section{Results}

\subsection{General Impacts of Village Committees on Farmers' Willingness of WRH}

In association with theoretical and contextual issues, the influencing mechanisms of farmers' willingness of WRH are examined in a BLR model with consideration of the heterogeneities of governance attributes and individual characteristics. We first analyzed the overall preferences of different respondents with the participation of village committees. The result is reported in Table 3.

Table 3. Farmers' willingness of WRH with the participation of village committees.

\begin{tabular}{|c|c|c|c|c|c|c|c|}
\hline \multirow{2}{*}{ Variables } & & \multicolumn{2}{|c|}{ WRH (\%) } & \multirow{2}{*}{ Variables } & & \multicolumn{2}{|c|}{ WRH (\%) } \\
\hline & & Willing & Unwilling & & & Willing & Unwilling \\
\hline \multirow{6}{*}{$\begin{array}{l}\text { Diversity of } \\
\text { publicity }\end{array}$} & 1 & 72.3 & 27.7 & \multirow{6}{*}{$\begin{array}{l}\text { Degree of democratic } \\
\text { decision-making }\end{array}$} & 1 & 72.3 & 27.7 \\
\hline & 2 & 91.4 & 8.6 & & 2 & 89.7 & 10.3 \\
\hline & 3 & 97.2 & 2.8 & & 3 & 74.4 & 25.6 \\
\hline & 4 & 88.2 & 11.8 & & 4 & 86.0 & 14.0 \\
\hline & 5 & 100.0 & 0.0 & & Average & 3.1 & 2.8 \\
\hline & Average & 1.8 & 1.3 & & & & \\
\hline \multirow{5}{*}{$\begin{array}{l}\text { Information } \\
\text { transparency }\end{array}$} & 1 & 15.4 & 84.6 & \multirow{6}{*}{ Interpersonal trust } & 1 & 31.8 & 68.2 \\
\hline & 2 & 55.8 & 44.2 & & 2 & 63.0 & 37.0 \\
\hline & 3 & 86.5 & 13.5 & & 3 & 87.1 & 12.9 \\
\hline & 4 & 91.1 & 8.9 & & 4 & 94.1 & 5.9 \\
\hline & 5 & 100.0 & 0.0 & & 5 & 82.1 & 17.9 \\
\hline \multirow{9}{*}{$\begin{array}{l}\text { Workload of the } \\
\text { village committee }\end{array}$} & Average & 3.5 & 2.3 & & Average & 3.4 & 2.4 \\
\hline & 0 & 64.7 & 35.3 & \multirow{8}{*}{ Institutional trust } & & & \\
\hline & 1 & 63.6 & 36.4 & & 1 & 21.1 & 78.9 \\
\hline & 2 & 87.5 & 12.5 & & 2 & 63.0 & 37.0 \\
\hline & 3 & 94.7 & 5.3 & & 3 & 87.6 & 12.4 \\
\hline & 4 & 80.0 & 20.0 & & 4 & 94.8 & 5.2 \\
\hline & 5 & 78.1 & 21.9 & & 5 & 80.0 & 20.0 \\
\hline & 6 & 93.3 & 6.7 & & Average & 3.5 & 2.4 \\
\hline & Average & 3.4 & 2.4 & & & & \\
\hline
\end{tabular}

First, farmers' willingness to withdraw from rural homesteads generally increases with the way publicity is diversifying. This implies the important role of village committees in farmers' better understanding of policies on WRH, as well as of their future development $[29,59,60]$. Similarly, higher policy transparency significantly improves the degree of farmers' willingness of WRH, whereas lower transparent policies tend to have negative effects. This suggests the importance of information availability in the process of WRH.

Compared with farmers under the management of village committees with less workload, their counterparts coordinated by those 'hardworking' committees were not necessarily more inclined to withdraw from their homesteads, suggesting that diligent leaders neither necessarily improve work efficiency in general nor improve farmers' willingness of WRH in particular. Instead, the workload of village committees only makes sense on average. Coincidently, farmers' willingness of WRH fluctuated with an increasing degree of democracy in village committees' decision-making process. 
This shows that the frequency of consultations with villagers may not directly have an impact on their final decisions regarding WRH. Rather, the details of consultations may matter.

From the perspective of trust building, farmers who are willing to withdraw from their homesteads have an average interpersonal trust level of 3.4, which is $42 \%$ higher than their unwilling counterparts, reflecting the importance of village committees' daily image in farmers' minds. Consistent with the impact of policy transparency, the changing trend of institutional trust echoes that of farmers' willingness of WRH excluding those at the highest level of trust. Yet, the average level of institutional trust indicates a similar pattern as interpersonal trust.

\subsection{Roles Played by Village Committees in WRH: A Multi-Mechanism Perspective}

To shed further light on the role of village committees, we applied the BLR model to investigate the determinants of WRH. The results are presented in Table 4. The significance value of the H-L test is 0.896 and most coefficients are statistically significant as expected, indicating that the BLR model is a satisfactory fit.

Table 4. Results of the binary logistic regression (BLR) model regression.

\begin{tabular}{lccc}
\hline \multicolumn{1}{c}{ Variables } & Coefficient & Standard Error & Significance \\
\hline Information intermediary & & & \\
Diversity of publicity & 0.638 & 0.289 & $0.027^{* *}$ \\
Information transparency & 0.866 & 0.245 & $0.000^{* * *}$ \\
Coordinated management & & & \\
Workload of the village committee & 0.192 & 0.099 & $0.053^{*}$ \\
Degree of democratic decision-making & -0.377 & 0.188 & $0.045^{*}$ \\
Trust building & & & 0.639 \\
Interpersonal trust & -0.141 & 0.302 & $0.066^{*}$ \\
Institutional trust & 0.578 & 0.314 & 0.833 \\
Control variables & & & 0.238 \\
Age & -0.067 & 0.318 & 0.398 \\
Gender & 0.018 & 0.015 & $0.055^{*}$ \\
Educational level & -0.164 & 0.194 & $0.019^{* *}$ \\
Proportion of migrant workers & 1.287 & 0.671 & $0.031^{* *}$ \\
Household annual net income & 0.217 & 0.092 & 0.578 \\
Total area of the contracted land & 0.222 & 0.103 & 0.839 \\
Total areas of the original homestead & 0.000 & 0.000 & $0.006^{* * *}$ \\
Land used period of the original homestead & 0.003 & 0.014 & \\
Constant & -4.67 & 1.685 & 207.666 \\
-2 log likelihood & & 0.254 & 0.410 \\
Cox \& Snell R Square & & & \\
Nagelkerke R Square & Chi-Square $=3.546$, Df $=8$, Significance $=0.896$ \\
H-L Test &
\end{tabular}

Note: ${ }^{* * *}, * *$, and $*$ represent significance at $1 \%, 5 \%$, and $10 \%$, respectively.

Variables representing information intermediary are the most significant variables related to farmers' willingness of WRH. Specifically, the degree of farmers' willingness increases by 0.638 and 0.866 when one unit increases concerning publicity diversity and information transparency, respectively. These indicate that the more diverse the publicity approaches of village committees are, the stronger the farmers' intention to withdraw from their homesteads is. The reason may be that village committees, as intermediaries for higher-level governments to transmit documents on WRH to rural households, which are much more skilled in publicizing those policies can significantly reduce the cost of villagers' accessibility to crucial information and enhance farmers' intention to withdraw from their homesteads.

Regarding the impact of coordinated management, the workload of village committees shows a significant positive relationship with the farmers' willingness to WRH at the statistical level of $10 \%$, which is consistent with the hypothesis that village committees play an important role as leaders, 
organizers, and coordinators in the process of rural restructuring [32,60]. In contrast, the democratic decision-making of village committees has a negative influence on farmers' willingness of WRH, which deviates from the theoretical hypothesis. The possible reason is that, villagers with strong and weak democratic preferences tend to coexist in the same community, which might be a puzzle for collective decision-making and to some extent reduce the efficiency of decision execution [61,62].

We also use two variables to describe the village committees' role in trust building, and the results show that farmers' willingness of WRH is affected by the institutional trust, namely farmers' trust in institutions is an impetus underlying WRH. The coefficient of "institutional trust" is significant and positive. However, the coefficient of "interpersonal trust" is negative and not statistically significant, suggesting a limited impact of farmers' trust in local cadres on their final decisions. The results show that, compared with interpersonal trust, institutional trust could provide a more standardized and reliable participation atmosphere for farmers, which increases the farmers' willingness on WRH.

\subsection{Impacts of Sample-Specific Characteristics: Explanation of Control Variables}

Given that rural homestead is nowadays not only a space for living but also a symbol of rural identity in China [27], social affiliation affects farmers' willingness of WRH more significantly than homestead characteristics. Thus, neither total area nor using period of land as homestead features is statistically significant. Additionally, the significant coefficients in the range from 0.217 to 1.287 for household attributes (i.e., the proportion of migrant workers, household annual net income, and the total area of contracted land) indicate that family background rather than individual characteristics of the respondents (mostly the head of rural household) played a vital role in WRH at the case level. This could be explained that WRH can greatly change the way of whole families' production and lifestyle and is a collective decision by all family members. Specifically, villagers are more inclined to withdraw from their homesteads with an increase in the proportion of migrant workers and a rise in the total net household income. Contrasting with the agriculture-based families, those with more members engaging in nonagricultural activities tend to have higher income and depend less on the rural economy $[63,64]$. Moreover, an increase in the area of contracted land also improves the degree of farmers' willingness to leave the homestead. This finding has been confirmed by Hao and Tang [65].

\section{Discussion}

\subsection{Main Findings: Triple Roles of Village Committees in the WRH}

The results showed that there is a close and significant relationship between the triple roles of village committees and the farmers' willingness on WRH, based on the descriptive statistical methods and BLR models. First, the role of village committees as information intermediaries has the most significant and positive impact, which echoes the study on village committees' role as information intermediary in farmland transfer by Shi et al. [35]. The participation of village committees can significantly reduce farmers' information costs, facilitate their understanding of policies.

Second, the role of village committees-as coordinated managers-matters in the WRH. As Zhang and Han [16] noted, both the breadth and depth of farmers' involvement in the WRH were limited given the complexity of rural land consolidation. The involvement of village committees is, therefore, significant in protecting farmers' interests. The deeper village committees participate in those processes, the more likely farmers can receive reasonable compensation and make positive decisions on the WRH. On the other hand, the efficiency depends heavily on the degree of villagers' participation. In rural China, the participation of villagers is restricted to the levels of "tokenism", which locates at the middle rungs of the "ladder of citizen participation" [66]. In other words, villagers, as powerless have-nots, lack the power to ensure their views are being heeded, though they are proffered to hear according to procedures. In this view, if farmers believe that the democratic decision-making of village committees is relatively "troublesome" and has limited impact, their enthusiasm to participate will be reduced. 
Third, village committees as policy transmitters in the WRH can gain villagers' trust in related policies. In other words, farmers tend to trust in policies issued by higher-level governments rather than local village cadres. On one hand, Chinese peasants are far more rational than being expected in making decisions related to their interests; on the other hand, most villagers remain skeptical about what local cadres say [52], due to inherent constraints on resources and power in contemporary China. Ironically, during our field visit to sample villages, we found that villagers were still willing to withdraw from their homesteads, even if they did not trust local cadres. The reason is that farmers appear to appreciate and trust the policies formulated by higher-level governments. This confirms the finding by Yang and Tang [67] — that institutional trust is more than a product of traditional values in China. Instead, it is resultant from an individual's rational choice based heavily on the evaluation of institutional performance and government-controlled politicization.

\subsection{Adaptabilities and Limitations of Village Committee Roles Initiatives}

In addition to the rural homesteads system reform, village committees tend to play an essential role in almost all village public affairs decisions. The explanation framework of village committees' roles thus could be widely used in the interpretation of related issues, such as rural land transfer, construction of village public roads, publicity, and implementation of major policies. Firstly, improving the authenticity and transparency of information will solve the issue of the information asymmetry between village committees and farmers. Secondly, we need to pay more attention to the effectiveness of democratic decision-making and local participation. Democratic consultation and participation in form will not bring the expected results. Thirdly, creating a more harmonious and trust relationship between the cadres and the peasantry by changing communication ways in daily life will not only affects the progress of the homestead system reform, but also smooth decision-making processes of village affairs. Fourthly, improving the institutional trust will help remove practical difficulties faced by village cadres.

The research limitations are as follows: (1) it is difficult to establish a theoretical framework to cover all roles of village committees, because the natural, cultural, social, and economic conditions of villages are quite different. We attempt to build this framework based on the basic functions of village committees; (2) Variables need to be adjusted in accordance with local conditions, to reflect the different roles of village committees in other public affairs and regions. (3) We mainly use the Likert scale method to develop indicators. This method cannot measure the efficiency of democratic decision-making.

\subsection{Policy Implications}

From a policy perspective, we argue that more efforts are still needed to facilitate the reform of rural homesteads and to implement the national strategies of rural revitalization. Firstly, various approaches and channels of communication between the village committee and farmers should be developed to enhance the intermediary role of village committees. Particularly, information disclosure systems need to be enhanced regarding relevant policies and information of public affairs. It should be noted that there is currently a lack of market information platforms for WRH, and the development of agricultural land transfer and transaction information platforms is still in the early stage. Thus, building a public market platform should be prioritized in the future. Secondly, considering the differences among villages, even within a county-level jurisdiction, in terms of both economic and social conditions, village committees should be empowered in decision-making regarding WRH. Thirdly, the involvement of farmers is essential for WRH and the development of the countryside [68]. Fourthly, we suggest trust can be built in the countryside by various collective activities and constructing formal policies on administrative credit.

\section{Conclusions}

Based on the field survey data in three pilot counties/districts of Sichuan province, China, we in this study analyzed the triple roles of village committees and investigated their impacts on the WRH. 
The results indicate that village committees' participation significantly affected farmers' willingness to withdraw from rural homesteads. Theoretically, the work reported in this paper initiated a conceptual framework on the roles of village committees, which might be beneficial to our better understanding of the village cadre-farmers nexus and more conducive to rural land system reform.

Taking the role of information intermediary, village committees can significantly improve villagers' willingness to withdraw from rural homesteads through effectively propagating information and explaining policies clearly. With respect to the role of coordinated managers, village committees are helpful in protecting the interest and benefit of those house-losing farmers, which is conducive to the orderly implementation of WRH. Yet, the democratic coordination of village committees is not always effective given the occasional occurrence of symbolically soliciting villagers' opinions. Regarding the role of trust builders, village committees are of great help in reducing the risk and cost of policy negotiation. Compared with interpersonal trust, institutional trust has a significantly positive role in WRH, indicating that the personal charm of village cadres has a limited impact and more formal institutional arrangements are needed in contemporary China.

Furthermore, we conclude that this study can be improved in the future by more case comparisons and analyses, particularly the trajectories of WRH in the eastern coast. Specifically, the following two directions are worthy of scholar attentions: (1) it is important to analyze the different characteristics of village committees in homestead exit, considering the differences in natural conditions and institutional backgrounds; (2) it is meaningful to identify factors such as the personal characteristics of village leaders and the acquaintances of rural communities, given that the personal characteristics and leadership styles of village cadres can affect the relationship between farmers and village committees.

Author Contributions: Conceptualization, P.T. and J.G.; methodology, P.T. and J.C.; validation, P.T., J.G., and M.L.; formal analysis, P.T., J.C., and J.G.; investigation, P.T. and J.C.; resources, P.T. and M.L.; data curation, P.T. and J.C.; writing—original draft preparation, P.T., J.C., and J.G.; writing—review and editing, P.T., J.G., and J.W.; project administration, P.T.; funding acquisition, P.T. All authors have read and agreed to the published version of the manuscript.

Funding: This research was financially supported by Sichuan Science and Technology Program (2020JDR0106), Sichuan Center for Rural Development Research Program (CR1917), the China Scholarship Council (201906245025), and National Natural Science Foundation of China (41971215).

Conflicts of Interest: The authors declare no conflict of interest.

\section{References}

1. Liu, Y.; Li, Y. Revitalize the world's countryside. Nature 2017, 548, 275-277. [CrossRef] [PubMed]

2. Lambin, E.F.; Meyfroidt, P. Land use transitions: Socio-ecological feedback versus socio-economic change. Land Use Policy 2010, 27, 108-118. [CrossRef]

3. Kates, R.W.; Parris, T.M. Long-term trends and a sustainability transition. Proc. Natl. Acad. Sci. USA 2003, 100, 8062. [CrossRef] [PubMed]

4. Long, H. Land Use Transitions and Rural Restructuring in China; Springer: Singapore, 2020.

5. Bai, X.; Shi, P.; Liu, Y. Realizing China's urban dream. Nature 2014, 509, 158-160. [CrossRef]

6. Li, L.; Liu, Y. Understanding the gap between de facto and de jure urbanization in China: A perspective from rural migrants' settlement intention. Popul. Res. Policy Rev. 2020, 39, 311-338. [CrossRef]

7. Gao, J.; Liu, Y.; Chen, J. China's initiatives towards rural land system reform. Land Use Policy 2020, 94, 104567. [CrossRef]

8. Zhou, Y.; Li, X.; Liu, Y. Rural land system reforms in China: History, issues, measures and prospects. Land Use Policy 2020, 91, 104330. [CrossRef]

9. Yu, Z.; Wu, C.; Tan, Y.; Zhang, X. The dilemma of land expansion and governance in rural China: A comparative study based on three townships in Zhejiang Province. Land Use Policy 2018, 71, 602-611. [CrossRef]

10. Gao, J.; Jiang, W.; Chen, J.; Liu, Y. Housing-industry symbiosis in rural China: A multi-scalar analysis through the lens of land use. Appl. Geogr. 2020, 124, 102281. [CrossRef] 
11. Long, H.; Li, Y.; Liu, Y.; Woods, M.; Zou, J. Accelerated restructuring in rural China fueled by 'increasing vs. decreasing balance' land-use policy for dealing with hollowed villages. Land Use Policy 2012, 29, 11-22. [CrossRef]

12. Liu, Y.; Liu, Y.; Chen, Y.; Long, H. The process and driving forces of rural hollowing in China under rapid urbanization. J. Geogr. Sci. 2010, 20, 876-888. [CrossRef]

13. Liu, Y.; Fang, F.; Li, Y. Key issues of land use in China and implications for policy making. Land Use Policy 2014, 40, 6-12. [CrossRef]

14. Zhu, X. Impact of the household registration system on farmers' rural housing land use decisions in China. Land 2017, 6, 75. [CrossRef]

15. Huang, X.; Li, H.; Zhang, X.; Zhang, X. Land use policy as an instrument of rural resilience-The case of land withdrawal mechanism for rural homesteads in China. Ecol. Indic. 2018, 87, 47-55. [CrossRef]

16. Zhang, X.; Han, L. Which factors affect farmers' willingness for rural community remediation? A tale of three rural villages in China. Land Use Policy 2018, 74, 195-203. [CrossRef]

17. Cao, Q.; Sarker, M.N.I.; Sun, J. Model of the influencing factors of the withdrawal from rural homesteads in China: Application of grounded theory method. Land Use Policy 2019, 85, 285-289. [CrossRef]

18. Wang, Q.; Zhang, M.; Cheong, K.-C. Stakeholder perspectives of China's land consolidation program: A case study of Dongnan Village, Shandong Province. Habitat Int. 2014, 43, 172-180. [CrossRef]

19. Fan, W.; Zhang, L. Does cognition matter? Applying the push-pull-mooring model to Chinese farmers' willingness to withdraw from rural homesteads. Pap. Reg. Sci. 2019, 98, 2355-2369. [CrossRef]

20. Gao, X.; Xu, A.; Liu, L.; Deng, O.; Zeng, M.; Ling, J.; Wei, Y. Understanding rural housing abandonment in China's rapid urbanization. Habitat Int. 2017, 67, 13-21. [CrossRef]

21. Chen, H.; Zhao, L.; Zhao, Z. Influencing factors of farmers' willingness to withdraw from rural homesteads: A survey in Zhejiang, China. Land Use Policy 2017, 68, 524-530. [CrossRef]

22. Zhang, L.; Fan, W. Rural homesteads withdrawal and urban housing market: A pilot study in China. Emerg. Mark. Financ. Trade 2020, 56, 228-242. [CrossRef]

23. Liu, Y.; Li, J.; Yang, Y. Strategic adjustment of land use policy under the economic transformation. Land Use Policy 2018, 74, 5-14. [CrossRef]

24. Zhao, Y. When guesthouse meets home: The time-space of rural gentrification in southwest China. Geoforum 2019, 100, 60-67. [CrossRef]

25. Kong, X.; Liu, Y.; Jiang, P.; Tian, Y.; Zou, Y. A novel framework for rural homestead land transfer under collective ownership in China. Land Use Policy 2018, 78, 138-146. [CrossRef]

26. Li, Y.; Liu, Y.; Long, H.; Cui, W. Community-based rural residential land consolidation and allocation can help to revitalize hollowed villages in traditional agricultural areas of China: Evidence from Dancheng County, Henan Province. Land Use Policy 2014, 39, 188-198. [CrossRef]

27. Gao, J.; Wu, Z.; Chen, J.; Chen, W. Beyond the bid-rent: Two tales of land use transition in contemporary China. Growth Chang. 2020, 51, 1336-1356. [CrossRef]

28. Chen, C.; Woods, M.; Chen, J.; Liu, Y.; Gao, J. Globalization, state intervention, local action and rural locality reconstitution-A case study from rural China. Habitat Int. 2019, 93, 102052. [CrossRef]

29. Long, H.; Tu, S.; Ge, D.; Li, T.; Liu, Y. The allocation and management of critical resources in rural China under restructuring: Problems and prospects. J. Rural Stud. 2016, 47, 392-412. [CrossRef]

30. Sargeson, S. Subduing "the rural house-building craze": Attitudes towards housing construction and land-use controls in four Zhejiang villages. China Q. 2002, 172, 927-955. [CrossRef]

31. Wang, M. Impact of the Global Economic Crisis on China's Migrant Workers: A Survey of 2700 in 2009. Eurasian Geogr. Econ. 2010, 51, 218-235. [CrossRef]

32. Wang, Y.; Chen, L.; Long, K. Farmers' identity, property rights cognition and perception of rural residential land distributive justice in China: Findings from Nanjing, Jiangsu Province. Habitat Int. 2018, 79, 99-108. [CrossRef]

33. Ma, S.; Mu, R. Forced off the farm? Farmers' labor allocation response to land requisition in China. World Dev. 2020, 132, 104980. [CrossRef]

34. Chen, C.; Gao, J.; Chen, J. Behavioral logics of local actors enrolled in the restructuring of rural China: A case study of Haoqiao Village in northern Jiangsu. J. Rural Stud. 2019, in press. [CrossRef]

35. Shi, X.; Chen, S.; Ma, X.; Lan, J. Heterogeneity in interventions in village committee and farmland circulation: Intermediary versus regulatory effects. Land Use Policy 2018, 74, 291-300. [CrossRef] 
36. Herbert-Cheshire, L. Contemporary strategies for rural community development in Australia: A governmentality perspective. J. Rural Stud. 2000, 16, 203-215. [CrossRef]

37. Landini, F.; Vargas, G.; Bianqui, V.; y Rebolé, M.I.M.; Martínez, M. Contributions to group work and to the management of collective processes in extension and rural development. J. Rural Stud. 2017, 56, 143-155. [CrossRef]

38. Iles, K.; Ma, Z.; Erwin, A. Identifying the common ground: Small-scale farmer identity and community. J. Rural Stud. 2020, 78, 25-35. [CrossRef]

39. Bukchin, S.; Kerret, D. The role of self-control, hope and information in technology adoption by smallholder farmers-A moderation model. J. Rural Stud. 2020, 74, 160-168. [CrossRef]

40. Onitsuka, K.; Hoshino, S. Inter-community networks of rural leaders and key people: Case study on a rural revitalization program in Kyoto Prefecture, Japan. J. Rural Stud. 2018, 61, 123-136. [CrossRef]

41. Msoffe, G.E.P.; Ngulube, P. Information sources preference of poultry farmers in selected rural areas of Tanzania. J. Librariansh. Inf. Sci. 2016, 49, 82-90. [CrossRef]

42. Hillman, B. The rise of the community in rural China: Village politics, cultural identity and religious revival in a Hui hamlet. China J. 2004, 51, 53-73. [CrossRef]

43. Gong, H. Study on policy "suspension" in rural area. J. Northwest AF Univ. (Soc. Sci. Ed.) 2017, 17, 51-57. Available online: http://www.xnxbs.net/xbnlkjdxskb/ch/reader/view_abstract.aspx?file_no=20170207\&flag=1 (accessed on 26 November 2020).

44. Bodin, Ö.; Crona, B.I. The role of social networks in natural resource governance: What relational patterns make a difference? Glob. Environ. Chang. 2009, 19, 366-374. [CrossRef]

45. Rogge, E.; Dessein, J.; Verhoeve, A. The organisation of complexity: A set of five components to organise the social interface of rural policy making. Land Use Policy 2013, 35, 329-340. [CrossRef]

46. Tan, R.; Heerink, N. Public and self-organized land readjustment in rural China-A comparison. J. Rural Stud. 2017, 53, 45-57. [CrossRef]

47. Wang, J.; Hochman, Z.; Taylor, B.; Darbas, T.; van Rees, H.; Carberry, P.; Ren, D. Governing through representatives of the community: A case study on farmer organizations in rural Australia. J. Rural Stud. 2017, 53, 68-77. [CrossRef]

48. Joop, K.; Klijn, E.-H. Managing Uncertainties in Networks: A Network Approach to Problem Solving and Decision Making; Routledge: London, UK, 2004.

49. Guo, L. Influence of transaction costs, trusting relationship on farmer's compliance behavior-Based on survey data from 286 apple growers in Shandong Province. J. Huazhong Agric. Univ. (Soc. Sci. Ed.) 2015, 56-61. Available online: http://hnxbw.cnjournals.net/hznydxsk/article/abstract/20150409 (accessed on 26 November 2020).

50. McCrea, R.; Walton, A.; Leonard, R. Rural communities and unconventional gas development: What's important for maintaining subjective community wellbeing and resilience over time? J. Rural Stud. 2019, 68, 87-99. [CrossRef]

51. Prazan, J.; Theesfeld, I. The role of agri-environmental contracts in saving biodiversity in the post-socialist Czech Republic. Int. J. Commons 2014, 8, 1-25. [CrossRef]

52. Lo, A.Y.; Cheung, L.T.O.; Lee, A.K.-Y.; Xu, B. Confidence and trust in public institution natural hazards management: Case studies in urban and rural China. Prof. Geogr. 2016, 68, 475-484. [CrossRef]

53. Prazan, J.; Dumbrovsky, M. Soil conservation policies: Conditions for their effectiveness in the Czech Republic. Land Degrad. Dev. 2011, 22, 124-133. [CrossRef]

54. Ieong, M.U. 'Know Who' may be better than 'Know How': Political connections and reactions in administrative disputes in China. J. Chin. Gov. 2019, 4, 233-251. [CrossRef]

55. Williamson, O.E. The Economic Institutions of Capitalism: Firms, Markets, Relational Contracting; Free Press: New York, NY, USA, 1985.

56. Liu, R.; Jiang, J.; Yu, C.; Rodenbiker, J.; Jiang, Y. The endowment effect accompanying villagers' withdrawal from rural homesteads: Field evidence from Chengdu, China. Land Use Policy 2020, 105107, in press. [CrossRef]

57. Shu, B.; Zhang, H.; Li, Y.; Qu, Y.; Chen, L. Spatiotemporal variation analysis of driving forces of urban land spatial expansion using logistic regression: A case study of port towns in Taicang City, China. Habitat Int. 2014, 43, 181-190. [CrossRef] 
58. Gao, J.; Yuan, F. Economic transition, firm dynamics, and restructuring of manufacturing spaces in urban China: Empirical evidence from Nanjing. Prof. Geogr. 2017, 69, 505-519. [CrossRef]

59. Tian, C.; Fang, L. The Impossible in China's Homestead Management: Free Access, Marketization and Settlement Containment. Sustainability 2018, 10, 798. [CrossRef]

60. Tu, S.; Long, H.; Zhang, Y.; Ge, D.; Qu, Y. Rural restructuring at village level under rapid urbanization in metropolitan suburbs of China and its implications for innovations in land use policy. Habitat Int. 2018, 77, 143-152. [CrossRef]

61. Pils, E. Assessing evictions and expropriations in China: Efficiency, credibility and rights. Land Use Policy 2016, 58, 437-444. [CrossRef]

62. Wang, Q. Public consultation: Settlement mechanism of preference intensity problems. J. Cent. China Norm. Univ. (Humanit. Soc. Sci.) 2010, 49, 158. Available online: http://journal.ccnu.edu.cn/sk/CN/abstract/ abstract4720.shtml (accessed on 26 November 2020).

63. Liu, L.; Gao, X.; Zhuang, J.; Wu, W.; Yang, B.; Cheng, W.; Xiao, P.; Yao, X.; Deng, O. Evaluating the lifestyle impact of China's rural housing land consolidation with locational big data: A study of Chengdu. Land Use Policy 2020, 96, 104623. [CrossRef]

64. Gao, J.; Liu, Y.; Chen, J.; Cai, Y. Demystifying the geography of income inequality in rural China: A transitional framework. J. Rural Stud. 2019, in press. [CrossRef]

65. Hao, P.; Tang, S. Floating or settling down: The effect of rural landholdings on the settlement intention of rural migrants in urban China. Environ. Plan. A 2015, 47, 1979-1999. [CrossRef]

66. Arnstein, S.R. A Ladder of Citizen Participation. J. Am. Inst. Plan. 1969, 35, 216-224. [CrossRef]

67. Yang, Q.; Tang, W. Exploring the Sources of Institutional Trust in China: Culture, Mobilization, or Performance? Asian Politics Policy 2010, 2, 415-436. [CrossRef]

68. Wang, X. Mutual empowerment of state and peasantry: Grassroots democracy in rural China. World Dev. 1997, 25, 1431-1442. [CrossRef]

Publisher's Note: MDPI stays neutral with regard to jurisdictional claims in published maps and institutional affiliations.

(C) 2020 by the authors. Licensee MDPI, Basel, Switzerland. This article is an open access article distributed under the terms and conditions of the Creative Commons Attribution (CC BY) license (http://creativecommons.org/licenses/by/4.0/). 